\title{
THE EFFECT OF THEOPHYLLINE WITH ETHYLENEDIAMINE (AMINOPHYLLINE) ON CEREBRAL HEMODYNAMICS IN THE PRESENCE OF CARDIAC FAILURE WITH AND WITHOUT CHEYNE-STOKES RESPIRATION ${ }^{1}$
}

\author{
By JOHN H. MOYER, SAM I. MILLER, ARTHUR B. TASHNEK, AND RUSSEL \\ BOWMAN WITH THE TECHNICAL ASSISTANCE OF MISS C. P. SMITH
}

\author{
(From the Departments of Medicine, Pharmacology and Biochemistry, Baylor University Col- \\ lege of Medicine, Houston, Texas)
}

(Submitted for publication September 17, 1951; accepted December 27, 1951)

Cheyne-Stokes respiration, found associated with cardiac failure, has been attributed to cerebral anoxia (1) on the basis of decreased cerebral blood flow, which is depressed in proportion to the decrease in cardiac output (2). Since Aminophylline increases cardiac output (3) and at the same time arrests Cheyne-Stokes respiration (4), it seems logical to conclude that the latter response occurs as a result of improvement of the cerebral circulation. However, Wechsler, Kleiss, and Kety (5) have observed that in normal individuals Aminophylline actually decreases cerebral blood flow. The following study was undertaken in order to clarify this problem. An attempt has been made to evaluate the effect of Aminophylline on the cerebral hemodynamics in 16 patients with cardiac failure, four of whom had Cheyne-Stokes respiration.

\section{METHODS AND MATERIAL}

Sixteen cerebral blood flow studies were done on patients with definite clinical and laboratory evidence of congestive heart failure. Their ages ranged from 38 to 70. All showed peripheral edema and signs of pulmonary congestion. The arm to tongue circulation times ranged between 17 and 55 seconds, and the venous pressures taken at the jugular bulb were above $10 \mathrm{~cm}$. water in all but two patients (Table I). Four presented the typical respiratory pattern of Cheyne-Stokes respiration (Table II). Azotemia, with blood urea nitrogens of 34 and 42 mg. per cent, was present in two patients (J. D. and D. B.). This was due to renal disease in the case of $J$. D. but was apparently secondary to the heart failure in the case of D. B., since there was no evidence of primary kidney disease in the latter. All but four patients had previously received treatment, but had become decompensated because of an inadequate regimen. The hemoglobin was not less than $10 \mathrm{gm}$. per cent in any of the

1 This study was aided in part by a grant from the $\mathrm{Na}$ tional Heart Institute of the National Institutes of Health, United States Public Health Service. patients. One of them (M. Y.) presented anxiety manifestations before the studies were started. These symptoms became accentuated after the Aminophylline was given. Additional pertinent clinical data are given in Table I.

The studies were carried out with the patients in the supine position. Two who were too orthopneic to lie supine were tilted to 20 degrees during the entire study. Measurements of pulse rate, respiratory rate, and auscultatory blood pressure were taken during the course of each experiment. Mean blood pressures were calculated on the basis of the diastolic pressure plus one-third of the pulse pressure. A control cerebral blood flow determination was completed employing the nitrous oxide method (6). Nitrous oxide was administered and blood samples collected over a 20 minute period, instead of the usual 10 , since equilibrium of nitrous oxide concentration was not always established at 10 minutes due to the decreased blood flow and low rate of arterial delivery of nitrous oxide to the brain. In the patients who exhibited Cheyne-Stokes respiration, when periods of apnea lasted more than 10 seconds, the respiratory rate and rhythm were consciously controlled by the patient at the direction of the investigator who administered the nitrous oxide. This was thought necessary in order to minimize variation in the arterial blood saturation curve of nitrous oxide. The variability seems to have been thus avoided since the arterial blood saturation curves appeared smooth and normal in each instance. Fluctuation in cerebral blood flow within the 10 minute period of study cannot be detected by the nitrous oxide technique since only the average blood flow is determined. Fifteen minutes after the control studies were completed, $0.5 \mathrm{gm}$. of Aminophylline in $10 \mathrm{ml}$. of saline was given intravenously over a five minute period. A cerebral blood flow determination was then repeated five minutes after giving the drug. In order to evaluate whether the effect of the drug on the cerebral circulation was transient or active over an extended period of time, a third cerebral blood flow determination was completed in six patients (Table II) 45 minutes after the drug was administered. Cerebral $\mathrm{O}_{2}$ consumption $\left(\mathrm{CMRO}_{2}\right)$ and cerebrovascular resistance (CVR) were calculated as previously described (6). The Van SlykeNeill manometric apparatus $(6,7)$ was used for blood gas analysis. Aerosol was used in place of saponin (8) as a hemolytic agent. 
TABLE I

Clinical status and respiratory, pulse rate, and blood pressure responses to A minophylline

\begin{tabular}{|c|c|c|c|c|c|c|}
\hline Patient & Sex & Age & Diagnosis & $\begin{array}{c}\text { Degree* } \\
\text { of } \\
\text { failure }\end{array}$ & Hct. & $\begin{array}{l}\text { Circ. time, } \\
\text { arm-tongue }\end{array}$ \\
\hline $\begin{array}{l}\text { B. W. } \\
\text { E. P. } \\
\text { E. W. } \\
\text { S. T. } \\
\text { A. J. }\end{array}$ & $\begin{array}{l}\mathbf{M} \\
\mathbf{M} \\
\mathbf{M} \\
\mathbf{M} \\
\mathrm{F}\end{array}$ & $\begin{array}{l}58 \\
34 \\
46 \\
65 \\
63\end{array}$ & $\begin{array}{l}\text { SHD, AI } \\
\text { Unknown } \\
\text { AI, RHD, MS } \\
\text { SHD, AI } \\
\text { HCVD }\end{array}$ & $\begin{array}{l}\text { IV } \\
\text { II } \\
\text { II } \\
\text { II } \\
\text { I }\end{array}$ & $\begin{array}{l}48 \\
38 \\
37 \\
40 \\
37\end{array}$ & $\begin{array}{l}35 \mathrm{sec} . \\
34 \mathrm{sec} . \\
21 \mathrm{sec} . \\
25 \mathrm{sec} . \\
20 \mathrm{sec} .\end{array}$ \\
\hline $\begin{array}{l}\text { M. Y. } \\
\text { A. L. } \\
\text { E. M. }\end{array}$ & $\begin{array}{l}\mathbf{M} \\
\mathbf{F} \\
\mathbf{M}\end{array}$ & $\begin{array}{l}44 \\
59 \\
46\end{array}$ & $\begin{array}{l}\text { HCVD } \\
\text { HCVD } \\
\text { RHD, }\end{array}$ & $\begin{array}{c}\text { I } \\
\text { II }\end{array}$ & $\begin{array}{l}48 \\
36 \\
55\end{array}$ & $\begin{array}{l}17 \mathrm{sec} . \\
35 \mathrm{sec} . \\
55 \mathrm{sec} .\end{array}$ \\
\hline $\begin{array}{l}\text { J. Y. } \\
\text { E. K. }\end{array}$ & $\stackrel{\mathrm{M}}{\mathrm{F}}$ & $\begin{array}{l}61 \\
56\end{array}$ & $\begin{array}{c}\text { SHD, AI } \\
\text { HCVD }\end{array}$ & $\begin{array}{l}\text { II } \\
\text { III }\end{array}$ & $\overline{42}$ & $\begin{array}{l}28 \mathrm{sec} \text {. } \\
50 \mathrm{sec} \text {. }\end{array}$ \\
\hline $\begin{array}{l}\text { J. D. } \\
\text { D. B. } \\
\text { W. H. } \\
\text { A. S. } \\
\text { C. M. } \\
\text { C. J. }\end{array}$ & $\begin{array}{l}\mathbf{M} \\
\mathbf{M} \\
\mathbf{M} \\
\mathbf{M} \\
\mathbf{M} \\
\mathbf{M}\end{array}$ & $\begin{array}{l}56 \\
56 \\
38 \\
57 \\
70 \\
62\end{array}$ & $\begin{array}{l}\text { HCVD } \\
\text { HCVD } \\
\text { ASHD } \\
\text { ASHD } \\
\text { ASHD } \\
\text { HCVD, AI }\end{array}$ & $\begin{array}{l}\text { II } \\
\text { II . } \\
\text { II } \\
\text { III } \\
\text { IV } \\
\text { II }\end{array}$ & $\begin{array}{l}36 \\
36 \\
39 \\
34 \\
30 \\
42\end{array}$ & $\begin{array}{l}20 \text { sec. } \\
25 \text { sec. } \\
28 \text { sec. } \\
34 \text { sec. } \\
38 \text { sec. } \\
35 \text { sec. }\end{array}$ \\
\hline Mean & & 54 & & & 40 & $31 \mathrm{sec}$. \\
\hline
\end{tabular}

* Graded (I-IV) on basis of severity of both objective and subjective manifestations of cardiac failure.

$\dagger$ Mean of control values for some six patients is 122 . SHD-Syphilitic heart disease

HCVD-Hypertensive cardiovascular disease

RHD-Rheumatic heart disease

ASHD-Arteriosclerotic heart disease

AI-Aortic insufficiency

MS-Mitral stenosis

\section{RESULTS}

The effect of Aminophylline on blood pressure, pulse rate, and respiration in the presence of heart failure is summarized in Table I. The data showing the cerebral hemodynamic response are presented in Table II. Although the blood pressure frequently decreased during the Aminophylline administration, it again became stabilized approximately at the control levels before the cerebral studies were repeated in most of the patients. After stabilization, there was not a statistically significant alteration of the mean blood pressure. It decreased in nine patients $(5 \mathrm{~mm}$. or more), increased in four, and in three there was no appreciable change. The effect on the pulse rate was likewise inconsistent. Contrary to the respiratory response in normal individuals (5), the respiratory rate did not increase significantly. However, there was usually an observable increase in the depth of respiration. This difference in response is

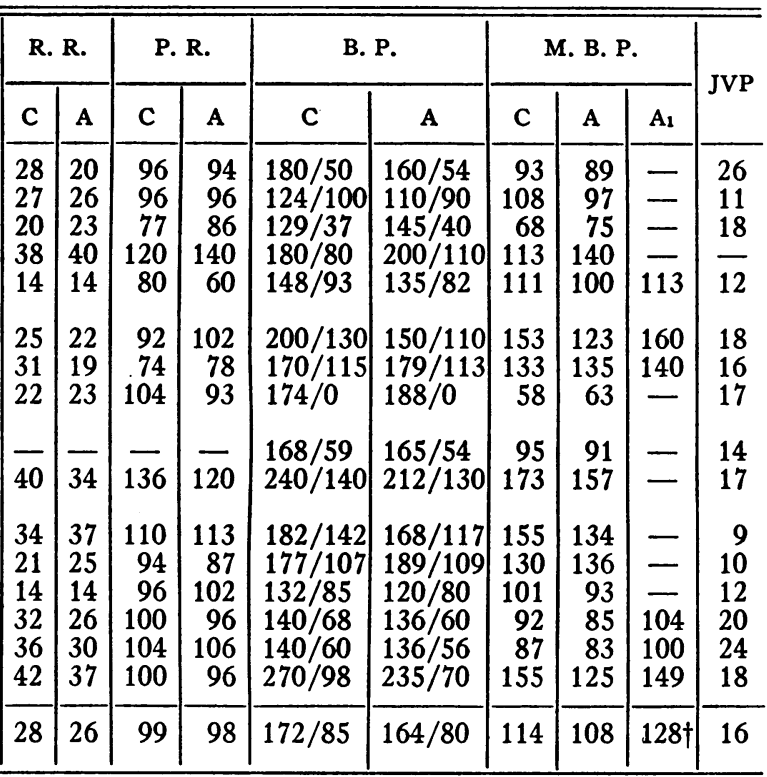

Hct.-Hematocrit

Circ. time- $5 \mathrm{ml}$. Decholin

R. R.-Respiratory rate

P. R.-Pulse rate

B. P.-Blood pressure

M. B. P.-Mean blood pressure (diastolic + pulse pressure/3)

C-Control observations

A-Five minutes after Aminophylline

$\mathrm{A}_{1}$-Forty-five minutes after Aminophylline

JVP-Control jugular bulb venous pressure, $\mathrm{cm}$. water.

probably due to the underlying cardiac disease, pulmonary congestion, and the resultant dyspneic state that already existed. The low arterial blood oxygen and carbon dioxide contents that were observed throughout the study were also a reflection of the type of patients studied, i.e., cardiac failure and associated pulmonary congestion (9). In addition, two of them exhibited uremia and four had previously received ammonium chloride as therapy for their disease which undoubtedly served to lower the plasma sodium and therefore the blood $\mathrm{CO}_{2}$ in these patients. All but four had received mercurial diuretics in the past. Despite the fact that the respiratory rate was not stimulated after the administration of Aminophylline, gaseous exchange within the lungs was somewhat improved. This was reflected in a decrease in the arterial $\mathrm{CO}_{2}$ content (average decrease $=1.8$ vol. per cent) in 14 of the 16 patients. In addition, the maximum concentration of nitrous oxide in the arterial blood 
was reached more rapidly after Aminophylline in most of the studies. However, probably due to its lower solubility, the arterial blood oxygen content was not significantly increased. Although the arterial $\mathrm{CO}_{2}$ decreased after Aminophylline, the jugular venous $\mathrm{CO}_{2}$ (acute changes in which would more closely reflect changes in tissue $\mathrm{CO}_{2}$ ) was not altered.

The control values for cerebral blood flow were below normal $(2,6,10)$, i.e., a mean of $45 \mathrm{ml}$. as compared to a mean of $54 \mathrm{ml}$. $(6,10)$ per minute per $100 \mathrm{gm}$. found in normal individuals. After Aminophylline, the cerebral blood flow became further reduced (mean $=30 \mathrm{ml}$. per minute per $100 \mathrm{gm}$.) in all but one patient. This was a result of an increase in cerebrovascular resistance (statistically, $\mathrm{p}<0.01$ ). In five patients the cerebral blood flow was decreased to $25 \mathrm{ml}$. per minute or below. This is a reduction of 50 per cent from the normal flow. Even at these low levels there was no obvious alteration of mental acuity.

As the cerebral blood flow decreased after Aminophylline, the oxygen content of the blood flowing from the brain was concurrently reduced (mean of 7.7 vol. per cent reduced to 6.5) resulting in an increased arteriovenous oxygen difference (mean of 7.2 increased to 8.7 vol. per cent). This compensatory phenomenon was incomplete with a resultant significant decrease in cerebral $\mathrm{O}_{2}$ utilization $\left(\mathrm{CMRO}_{2}\right)$. The cerebral hemodynamic effects are summarized in Figure 1.

There appeared to be no essential difference in the hemodynamic response immediately or 45 minutes after the administration of Aminophylline (Table II). The patients displaying CheyneStokes respiration (Table II) showed no difference in cerebral hemodynamic response to Aminophylline from that of the other patients in cardiac fail-

TABLE II

Cerebral hemodynamic effect of Aminophylline

\begin{tabular}{|c|c|c|c|c|c|c|c|c|c|c|c|c|c|c|c|c|c|c|}
\hline \multirow{2}{*}{ Patient } & \multicolumn{2}{|c|}{$\begin{array}{l}\text { Art. } \\
\text { (ool. per cent) }\end{array}$} & \multicolumn{2}{|c|}{$\begin{array}{l}\text { Ven. } \mathrm{CO}_{2} \\
\text { (nol. per cent) }\end{array}$} & \multicolumn{2}{|c|}{$\begin{array}{l}\text { Art. } O_{2} \\
\text { (oot. per cent) }\end{array}$} & \multicolumn{2}{|c|}{$\begin{array}{l}\text { Ven. Oz } \\
\text { (rod. } \\
\text { per cent) }\end{array}$} & \multicolumn{3}{|c|}{$\begin{array}{c}\text { (ood. per cent) } \\
\text { A } \mathrm{O}_{2}\end{array}$} & \multicolumn{3}{|c|}{ CBF* } & \multicolumn{2}{|c|}{$\mathrm{CMRO}_{2} \dagger$} & \multicolumn{2}{|c|}{ CVR $\ddagger$} \\
\hline & c & $\mathbf{A}$ & C & A & C & A & C & $\mathbf{A}$ & C & A & $\mathbf{A}_{\mathbf{1}}$ & C & A & $\mathbf{A}_{\mathbf{1}}$ & C & A & C & A \\
\hline $\begin{array}{l}\text { B. W. } \\
\text { E. P. } \\
\text { E. W. } \\
\text { S. T. } \\
\text { A. J. }\end{array}$ & $\begin{array}{l}35.0 \\
48.4 \\
34.2 \\
36.7 \\
41.9\end{array}$ & $\begin{array}{l}32.4 \\
47.7 \\
34.9 \\
34.3 \\
38.5\end{array}$ & $\begin{array}{l}42.2 \\
55.0 \\
42.0 \\
40.2 \\
47.4\end{array}$ & $\begin{array}{l}44.3 \\
56.6 \\
42.8 \\
42.8 \\
47.5\end{array}$ & $\begin{array}{l}15.2 \\
14.7 \\
15.6 \\
11.8 \\
16.6\end{array}$ & $\begin{array}{l}15.4 \\
14.8 \\
16.1 \\
13.3 \\
13.2\end{array}$ & $\begin{array}{l}6.5 \\
7.5 \\
7.7 \\
7.3 \\
9.7\end{array}$ & $\begin{array}{l}4.1 \\
6.5 \\
8.0 \\
5.8 \\
5.2\end{array}$ & $\begin{array}{l}8.7 \\
7.2 \\
7.9 \\
4.5 \\
6.9\end{array}$ & $\begin{array}{r}11.3 \\
8.3 \\
8.1 \\
7.5 \\
8.0\end{array}$ & $\begin{array}{l}\bar{z} \\
\frac{Z}{8.8}\end{array}$ & $\begin{array}{l}31 \\
57 \\
37 \\
61 \\
50\end{array}$ & $\begin{array}{l}21 \\
35 \\
34 \\
32 \\
30\end{array}$ & $\begin{array}{l}\bar{Z} \\
\overline{2}\end{array}$ & $\begin{array}{l}2.7 \\
4.1 \\
2.9 \\
2.7 \\
3.5\end{array}$ & $\begin{array}{l}2.4 \\
2.9 \\
2.8 \\
2.4 \\
2.4\end{array}$ & $\begin{array}{l}3.0 \\
1.9 \\
1.8 \\
1.9 \\
2.2\end{array}$ & $\begin{array}{l}4.2 \\
2.8 \\
2.2 \\
4.4 \\
3.3\end{array}$ \\
\hline $\begin{array}{l}\text { M.Y. } \\
\text { A. L.\& } \\
\text { E. M. } 8 \\
\text { J.Y. Y } \\
\text { E. K. } \&\end{array}$ & $\begin{array}{l}31.1 \\
29.5 \\
20.6 \\
26.7 \\
24.9\end{array}$ & $\begin{array}{l}30.8 \\
24.6 \\
19.8 \\
26.2 \\
22.8\end{array}$ & $\begin{array}{l}39.5 \\
35.0 \\
28.2 \\
31.0 \\
33.7\end{array}$ & $\begin{array}{l}39.2 \\
33.5 \\
29.4 \\
32.0 \\
31.1\end{array}$ & $\begin{array}{l}15.6 \\
17.6 \\
14.7 \\
12.7 \\
16.6\end{array}$ & $\begin{array}{l}16.6 \\
17.8 \\
17.9 \\
13.2 \\
15.9\end{array}$ & $\begin{array}{r}6.8 \\
10.8 \\
6.3 \\
8.0 \\
9.4\end{array}$ & $\begin{array}{l}5.8 \\
9.7 \\
5.3 \\
8.2 \\
8.4\end{array}$ & $\begin{array}{l}8.8 \\
6.8 \\
8.4 \\
4.7 \\
7.2\end{array}$ & $\begin{array}{r}10.8 \\
8.1 \\
12.6 \\
5.0 \\
7.5\end{array}$ & $\begin{array}{l}9.7 \\
6.2 \\
= \\
-\end{array}$ & $\begin{array}{l}47 \\
44 \\
39 \\
40 \\
58\end{array}$ & $\begin{array}{l}54 \\
30 \\
16 \\
36 \\
35\end{array}$ & $\begin{array}{l}48 \\
36 \\
- \\
-\end{array}$ & $\begin{array}{l}4.1 \\
3.0 \\
3.3 \\
1.9 \\
4.2\end{array}$ & $\begin{array}{l}5.8 \\
2.4 \\
2.0 \\
1.8 \\
2.6\end{array}$ & $\begin{array}{l}3.3 \\
3.0 \\
1.5 \\
2.4 \\
3.0\end{array}$ & $\begin{array}{l}2.3 \\
4.5 \\
3.9 \\
2.5 \\
4.5\end{array}$ \\
\hline $\begin{array}{l}\text { J. D.\|l } \\
\text { D. B. } \\
\text { W. H. } \\
\text { A. S. } \\
\text { C. M. M } \\
\text { C. J.** }\end{array}$ & $\begin{array}{l}19.2 \\
31.7 \\
33.4 \\
38.5 \\
41.0 \\
30.8\end{array}$ & $\begin{array}{l}18.8 \\
32.8 \\
31.0 \\
33.7 \\
39.0 \\
27.5\end{array}$ & $\begin{array}{l}25.8 \\
38.6 \\
38.2 \\
42.5 \\
47.4 \\
37.8\end{array}$ & $\begin{array}{l}26.0 \\
39.4 \\
39.5 \\
42.3 \\
47.5 \\
37.0\end{array}$ & $\begin{array}{l}11.9 \\
12.7 \\
13.4 \\
17.8 \\
15.7 \\
15.9\end{array}$ & $\begin{array}{l}12.8 \\
12.2 \\
13.2 \\
17.6 \\
16.3 \\
16.4\end{array}$ & $\begin{array}{r}5.4 \\
4.3 \\
7.7 \\
11.0 \\
7.6 \\
7.9\end{array}$ & $\begin{array}{l}4.1 \\
3.5 \\
5.0 \\
9.9 \\
7.2 \\
7.4\end{array}$ & $\begin{array}{l}6.5 \\
8.4 \\
5.7 \\
6.8 \\
8.1 \\
8.0\end{array}$ & $\begin{array}{l}8.7 \\
8.7 \\
8.2 \\
7.7 \\
9.1 \\
9.0\end{array}$ & $\begin{array}{l}\overline{-} \\
\overline{6.1} \\
9.7 \\
9.7\end{array}$ & $\begin{array}{l}55 \\
41 \\
51 \\
45 \\
35 \\
32\end{array}$ & $\begin{array}{l}25 \\
33 \\
33 \\
30 \\
20 \\
18\end{array}$ & $\begin{array}{l}\text { 二 } \\
\overline{36} \\
22 \\
20\end{array}$ & $\begin{array}{l}3.6 \\
3.4 \\
2.9 \\
3.1 \\
2.8 \\
2.6\end{array}$ & $\begin{array}{l}2.2 \\
2.9 \\
2.7 \\
2.3 \\
1.8 \\
1.6\end{array}$ & $\begin{array}{l}2.8 \\
3.2 \\
2.0 \\
2.0 \\
2.5 \\
4.8\end{array}$ & $\begin{array}{l}5.4 \\
4.1 \\
2.8 \\
2.8 \\
4.2 \\
6.9\end{array}$ \\
\hline Mean & 32.7 & 30.9 & 39.0 & 39.4 & 14.9 & 15.2 & 7.7 & 6.5 & 7.2 & $8.7 \mathrm{tt}$ & 8.4 & $45 \mathrm{t \dagger}$ & $30 \ddagger t$ & 31 & 3.2 & $2.6 \pm t$ & 2.6 & $3.8 t t$ \\
\hline
\end{tabular}

C-Control.

A-Five minutes after $0.5 \mathrm{gm}$. Aminophylline intravenously.

$\mathrm{A}_{1}$ - Forty-five minutes after Aminophylline.

* CBF-Cerebral blood flow, ml. $/ 100 \mathrm{gm}$. $/ \mathrm{min}$.

t $\mathrm{CMRO}_{2}-\mathrm{O}_{2}$ consumption, ml. $/ 100 \mathrm{gm}$. $/ \mathrm{min}$.

CVR-Cerebrovascular resistance, $M B P / C B F /$ min.

8 Patient received ammonium chloride as diuretic for prolonged period but discontinued three or more days before present study.

II Associated uremia-J. D., 34 mg. \%; D. B., 42 mg. \%.

I Cheyne-Stokes respiration present which was relieved by Aminophylline.

** Cheyne-Stokes respiration not relieved by Aminophylline.

tt Mean value in normal subjects $=54 \mathrm{ml} . / 100 \mathrm{gm} . / \mathrm{min} .(6,10)$.

$\#$ Statistically significant $p<0.01$. 


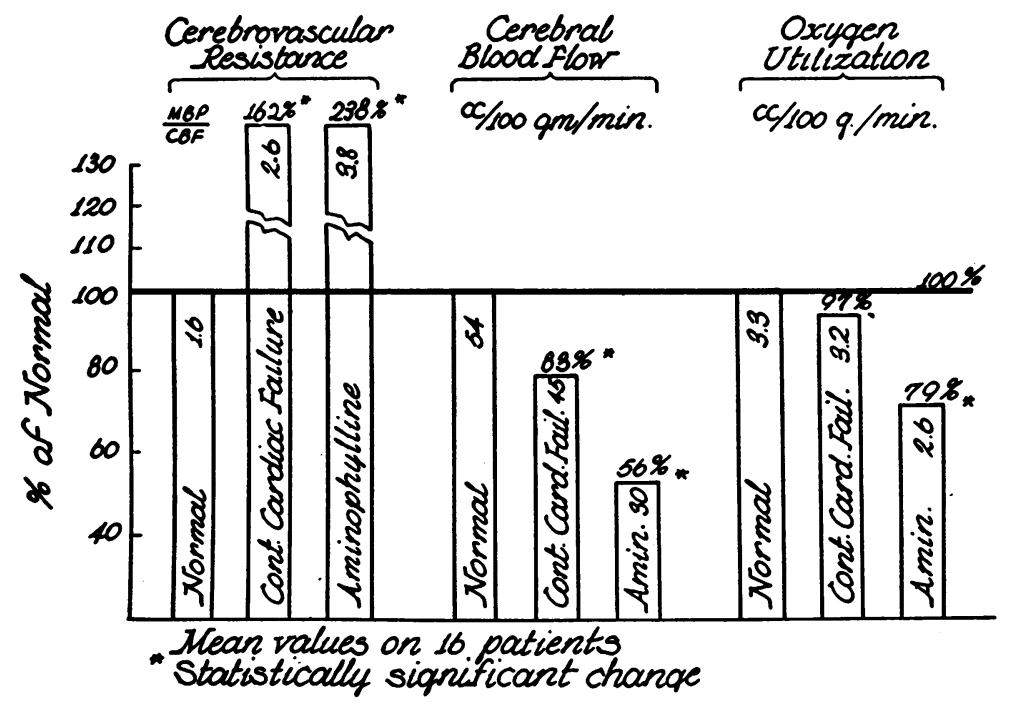

Fig. 1. Cerebral Hemodynamic Changes in Patients with Cardiac Failure, before and after Aminophylline, Compared with the Normal.

ure. After the drug, normal rhythmical breathing returned in three of the four patients.

\section{DISCUSSION}

The cause of the high initial cerebrovascular resistance and resultant decreased cerebral blood flow in this group of patients exhibiting heart failure is not apparent (2). The highest values for cerebrovascular resistance were seen in those patients with concurrent hypertension. Kety (11) has suggested that increased venous pressure may impede the outflow of blood from the brain. There was no correlation between venous pressure and depressed cerebral flow in the present study. Lowered arterial $\mathrm{pCO}_{2}$ (not determined in the present study) has also been shown to decrease cerebral blood flow (12). Further studies under these circumstances will be necessary to reach definite conclusions on this point in patients with cardiac failure.

The cerebral blood flow decreased after Aminophylline in all but one patient. The associated acute reduction in arterial $\mathrm{CO}_{2}$ content, which occurred after the drug was administered in 14 out of 16 patients must reflect, at least qualitatively, a reduction in $\mathrm{pCO}_{2}$, since only through increased gas exchange in the lungs could this occur so rapidly (five to 10 minutes). Thus, the reduced arterial $\mathrm{CO}_{2}$ may be a factor in the depression of cerebral blood flow after Aminophylline. If so, it is only a minor factor because when changes in cerebral blood flow of this magnitude due to hyperventilation (12) are compared to the present observations, one may note that decreased $\mathrm{CO}_{2}$ of a much greater magnitude was required to significantly alter cerebral blood flow. In addition, there is no statistical correlation between reduction in cerebral blood flow and the reduction in arterial $\mathrm{CO}_{2}$. Moreover, when cerebral blood flow is reduced by acute reduction in arterial $\mathrm{CO}_{2}$ following hyperventilation, the jugular $\mathrm{CO}_{2}$ also decreases. In the present group of patients (Table II), the $\mathrm{CO}_{2}$ content of the blood coming from the brain did not change. Since the jugular blood more closely reflects the state of affairs in brain tissue than does arterial blood, one is led to the conclusion that low $\mathrm{CO}_{2}$ in the cerebral tissue should be discarded as a responsible factor for the depressed cerebral blood flow after Aminophylline. We therefore conclude, as Wechsler, Kleiss, and Kety (5) have done in similar observations on normal individuals, that the increase in cerebrovascular resistance and decrease in cerebral blood flow is probably a direct effect of Aminophylline on the cerebral vessels. In fact, the small but consistent reduction in arterial $\mathrm{CO}_{2}$ after Aminophylline, as noted above, could well result from the depressed cerebral blood flow rather than being a causative factor. If so, the increased depth of respiration and improved gaseous exchange would result from the 
medullary hemostasis with its accompanying rise in tissue $\mathrm{CO}_{2}$, thus producing stimulation of the respiratory center (1). Increase in cardiac output with improvement of the pulmonary circulation and the relief of pulmonary edema has not been ruled out as a contributing factor to the decrease in arterial $\mathrm{CO}_{2}$. The phenomenal increase in cerebrovascular resistance and reduction in cerebral blood flow to levels that have not heretofore been observed indicates that the vasoconstrictive effect of this drug has been superimposed on the increased vascular resistance that is already present in cardiac failure (2). Even in those patients exhibiting hypertension (13), there is a further increase in cerebrovascular resistance after Aminophylline.

In view of the reported cerebral stimulant effect of Aminophylline (1), the decrease in the coefficient of oxygen utilization after the administration of the drug seems paradoxical. Although the arteriovenous oxygen difference increases in an apparent attempt to compensate for the decreased cerebral blood flow, the release of oxygen from the blood is not adequate. This is in contrast to the findings in normal individuals (5), and probably is reflected in the hemoglobin saturation curve of oxygen. Since hemoglobin is inadequately saturated with oxygen in patients with pulmonary congestion, the low $\mathrm{pO}_{2}$ portion of the curve is more rapidly attained as oxygen is released at the tissue level, especially with cerebral blood flow values in the range of 20 to $30 \mathrm{ml}$. per minute. Thus, it becomes increasingly difficult for the blood to release an adequate amount of oxygen under these circumstances.

It was anticipated that the mechanism of effect of Aminophylline in arresting Cheyne-Stokes respiration was by improving cerebral blood flow, and thus relieving cerebral anoxia. This was shown not to occur, since those patients with Cheyne-Stokes respiration showed no difference in cerebral hemodynamic response to Aminophylline from the other patients in cardiac failure. The cerebral blood flow and the coefficient of oxygen utilization $\left(\mathrm{CMRO}_{2}\right)$ both decreased significantly. One would conclude from these observations that the therapeutic effect of Aminophylline in arresting Cheyne-Stokes respiration in the patients studied is probably due to a stimulating effect on the respiratory center. This may be due to a direct effect on the center or an indirect effect by increasing the medullary $\mathrm{CO}_{2}$ resulting from circulatory stasis.

It is of interest that one patient (M. Y.) showed signs of anxiety which were aggravated by Aminophylline. This is the only patient who showed an increase of oxygen utilization without a decrease in cerebral blood flow. Contrariwise, when the cerebral blood flow decreased to less than half the normal rate in a number of individuals there was no obvious disturbance of cerebration. This fact suggests that consideration of a reduction in cerebral blood flow as a cause of altered cerebral function, rather than merely as an associated finding, must be viewed with caution.

\section{CONCLUSIONS}

1. Aminophylline increases the cerebrovascular resistance in patients with cardiac failure. As a result, the cerebral blood flow decreases.

2. Although the arterial blood $\mathrm{CO}_{2}$ content usually decreases (14 of 16 patients) after Aminophylline, these changes are not great enough to be statistically significant. The jugular $\mathrm{CO}_{2}$ increases, or it does not change. Therefore, the depression of cerebral blood flow is not a reflection of decreased $\mathrm{CO}_{2}$ in the brain. It is more likely a direct effect of Aminophylline on the cerebral vessels.

3. Although the arteriovenous oxygen differences increase as a partial compensation for the decreased blood flow, compensation is inadequate. Therefore, the cerebral oxygen consumption appears to decrease when Aminophylline is given to patients with cardiac failure.

4. There is no difference in the over-all cerebral hemodynamic response of patients in cardiac failure manifesting Cheyne-Stokes respiration and those with regular respiration. The arrest of Cheyne-Stokes respiration after Aminophylline cannot be attributed to an increase of the cerebral blood flow. It is probably due to a stimulating effect on the respiratory center. This may be a direct effect or an indirect effect secondary to the depressed cerebral circulation and the resultant rise in medullary tissue $\mathrm{CO}_{2}$. The fact that this effect of Aminophylline has been observed for at least one hour also indicates that it is not a transient response during the phase of readjustment of the cardiovascular hemodynamics. 


\section{REFERENCES}

1. Goodman, L., and Gilman, A., Pharmacological Basis of Therapeutics: A Textbook of Pharmacology, Toxicology and Therapeutics for Physicians and Medical Students. Macmillan Co., New York, 1941.

2. Scheinberg, $P$., Cerebral circulation in heart failure. Am. J. Med., 1950, 8, 148.

3. Starr, I., Gamble, C. J., Margolies, A., Donal, J. S., Jr., Joseph, N., and Eagle, E., A clinical study of the action of 10 commonly used drugs on cardiac output, work and size; on respiration, on metabolic rate, and on the electrocardiogram. J. Clin. Invest., 1937, 16, 799.

4. Greene, J. A., and Heeren, R. H., Observations on Cheyne-Stokes respiration: the effect of drugs and mechanical measures which produce vasodilatation and vasoconstriction, in: Medical Papers dedicated to Henry A. Christian, edited by Monroe, R. T. Waverly Press, Baltimore, 1936, p. 51.

5. Wechsler, R. L., Kleiss, L. M., and Kety, S. S., The effects of intravenously administered Aminophylline on cerebral circulation and metabolism in man. J. Clin. Invest., 1950, 29, 28.

6. Kety, S. S., and Schmidt, C. F., The nitrous oxide method for the quantitative determination of cerebral blood flow in man: theory, procedure and normal values. J. Clin. Invest., 1948, 27, 476.

7. Peters, J. P., and Van Slyke, D. D., Quantitative Clinical Chemistry. Vol. II, Methods. Williams \& Wilkins, Baltimore, 1932.

8. Yiengst, M. J., A new hemolytic agent for the manometric determination of the oxygen content of blood. Science, 1950, 112, 205.

9. Altschule, M. D., Physiology in Diseases of the Heart and Lungs. Harvard Univ. Press, Cambridge, 1950, p. 76.

10. Moyer, J. H., Unpublished data.

11. Kety, S. S., Circulation and metabolism of the humar. brain in health and disease. Am. J. Med., 1950, 8. 205.

12. Kety, S. S., and Schmidt, C. F., The effects of active and passive hyperventilation on cerebral blood flow, cerebral oxygen consumption, cardiac output and blood pressure of normal young men. J. Clin. Invest., 1946, 25, 107.

13. Hafkenschiel, J. H., Crumpton, C. W., Moyer, J. H., and Jeffers, W. A., The effects of dihydroergocornine on the cerebral circulation in patients with essential hypertension. J. Clin. Invest., 1950, 29, 408 . 